Journal of Engineering Sciences, Assiut University, Vol. 36, No. 2, pp. 549-567, March 2008

\title{
FEATURES OF THE URBAN FORM FOR WATERFRONT ZONES \\ CASE STUDY: THE URBAN FORM ALONG SUEZ CANAL
}

\section{Essam Badran Abo El-Enyen}

Associate Professor, Department of Architecture \& Urban Planning,

Faculty of Engineering, Suez Canal University, Egypt

\section{Mohammed Hassan Atwa}

Associate Professor, Department of Architecture \& Urban Planning,

Faculty of Engineering, Suez Canal University, Egypt

\section{Noha Mohammed Abo Samra}

Demonstrator, Department of Architecture \& Urban Planning, Faculty of Engineering, Suez Canal University, Egypt

(Received December 25, 2007 Accepted January 15, 2008)

The relationship between the urban formation and its respect to the physical environment is always considered as an important issue. But nowadays the effect of the natural environment on the urban form became so weak and the connection with the surrounding landscape is extremely neglected.

The research aims to study the attractive characteristics and features of urban formation for waterfront zones through:

First: Theoretical Approach: It involves the study of the relationship between the urban formation and the waterfront zones from three different views "natural, historical, and, urban".

Second: Field Study Approach: This part contains the study of the features of urban formation for waterfront zones along Suez Canal. The paper presents the history of the Suez Canal cities "Port said-IsmailiaSuez" and discusses the current situation of them. Then, it analyses the urban form of them on different levels:" planning, urban design and architectural level".

Finally the paper gives some recommendations for strategic planning, urban design and environmental design.
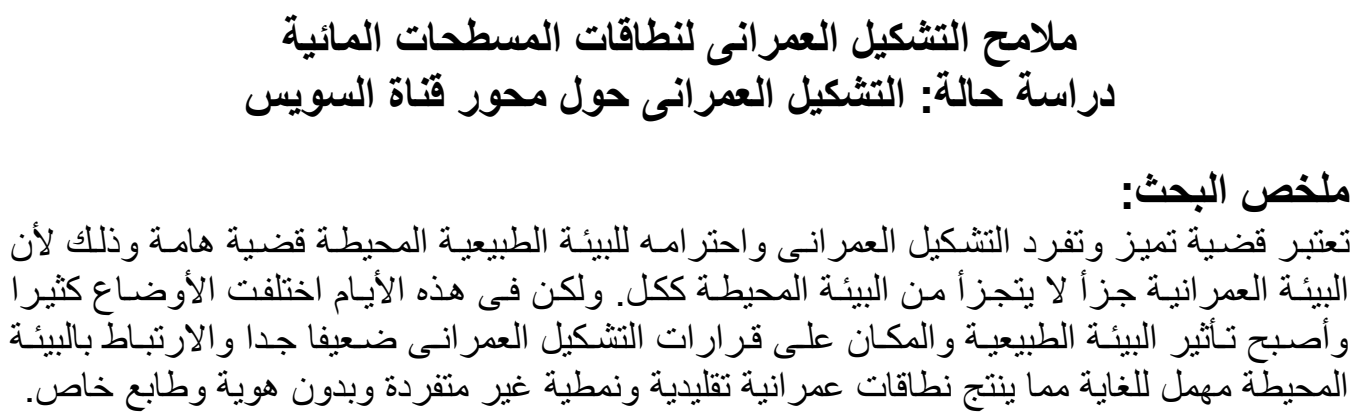


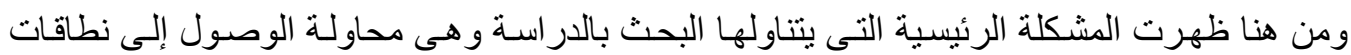

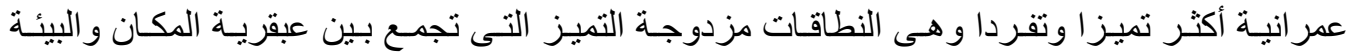
الطبيعية من ناحية و المظهر العمر انى المتميز من الطئ ناحية.

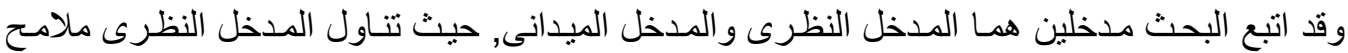

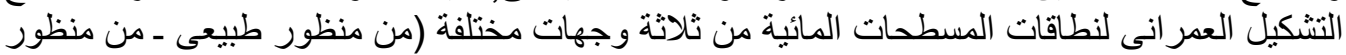

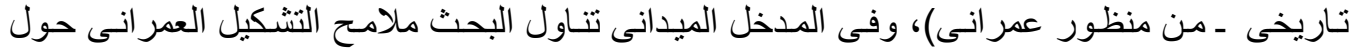

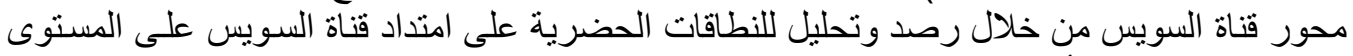

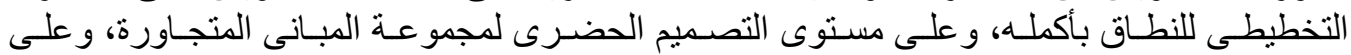

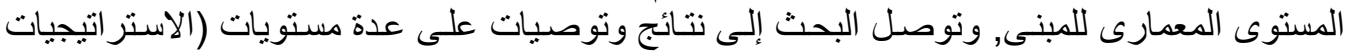

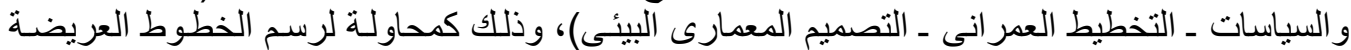

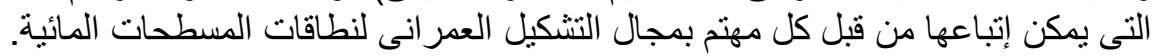

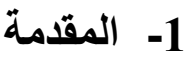

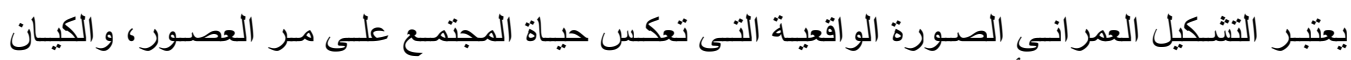

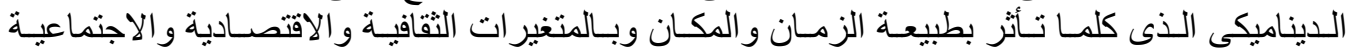

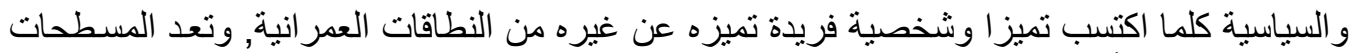

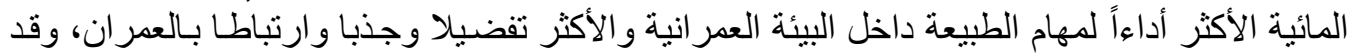

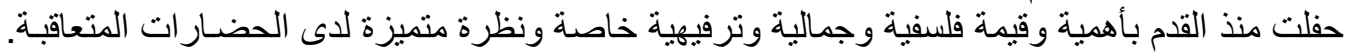

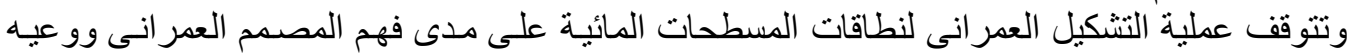

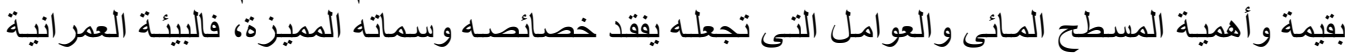

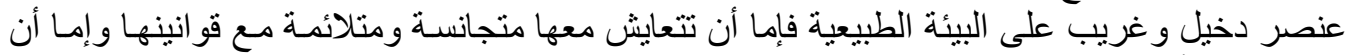

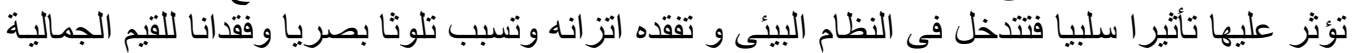

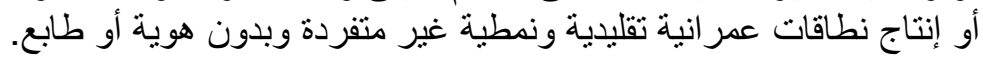

هدف البحث: يهذف البحث إلى بلورة وصياغة ملامسح التشكيل العمر انى لنطاقات المسطحات المائيسة

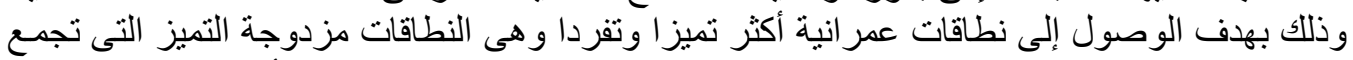

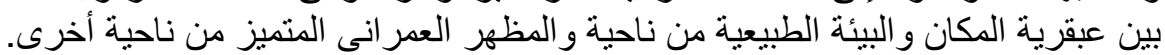

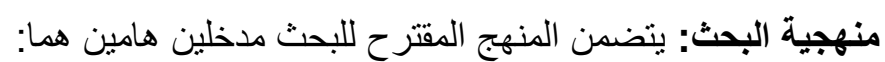

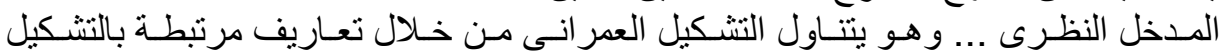

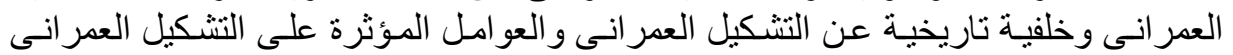

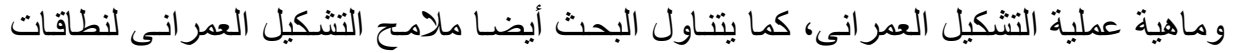

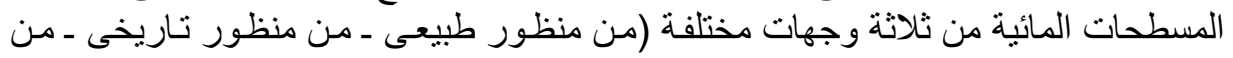
منظور عمر انى).

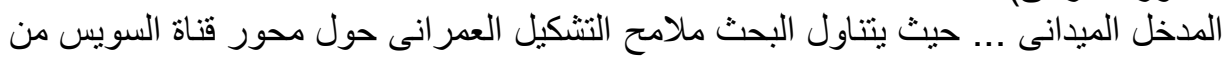

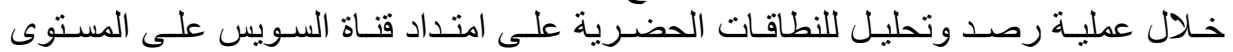

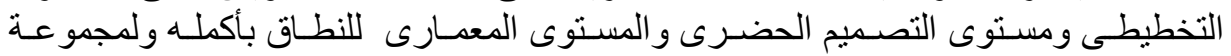

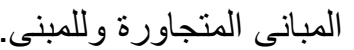




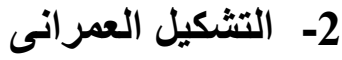

2 - 1 - 1 تعريف التثكيل العمرانى

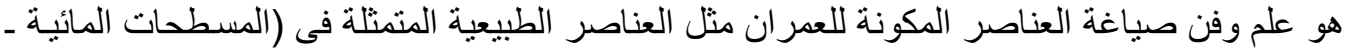

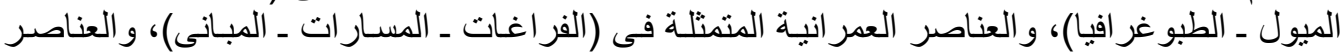
الإنسانية المنمثلة فى (الأنشطة ـ العادات ـ التقاليد) [ 1 1].

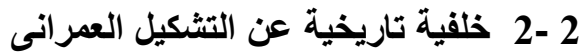

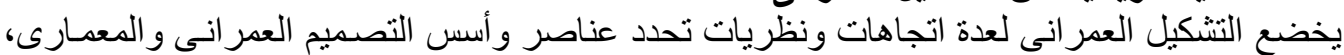

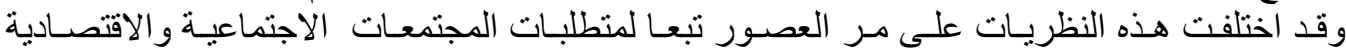
و السياسية والدينية و الثقافية التى تختلف من عصر لآخر.

جدول (1) خلفية تاريخية عن التثكيل العمرانى

\begin{tabular}{|c|c|c|c|c|}
\hline \multicolumn{2}{|l|}{ شكل المدينة } & للتثكيل العمرانى & العلى التثكيل المؤثرة & التاريخية \\
\hline affing & 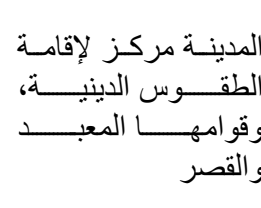 & 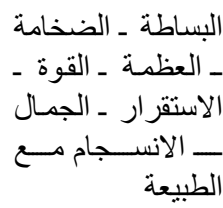 & العو العو امل الجغرينية & (الفبل المعلادي \\
\hline & 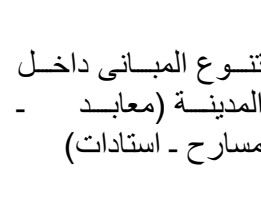 & 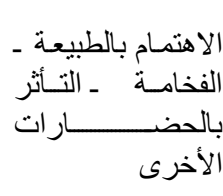 & العو العو امل الدينية العلية & والاغريقيى \\
\hline & 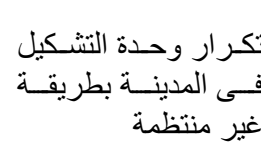 & 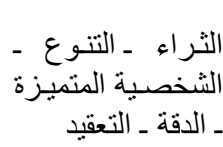 & العو العو الجل الدينية العنبة & (القرن اللامىم) \\
\hline & & & & \\
\hline
\end{tabular}


تابع جدول (1) خلقية تاريخية عن التثكيل العمرانى

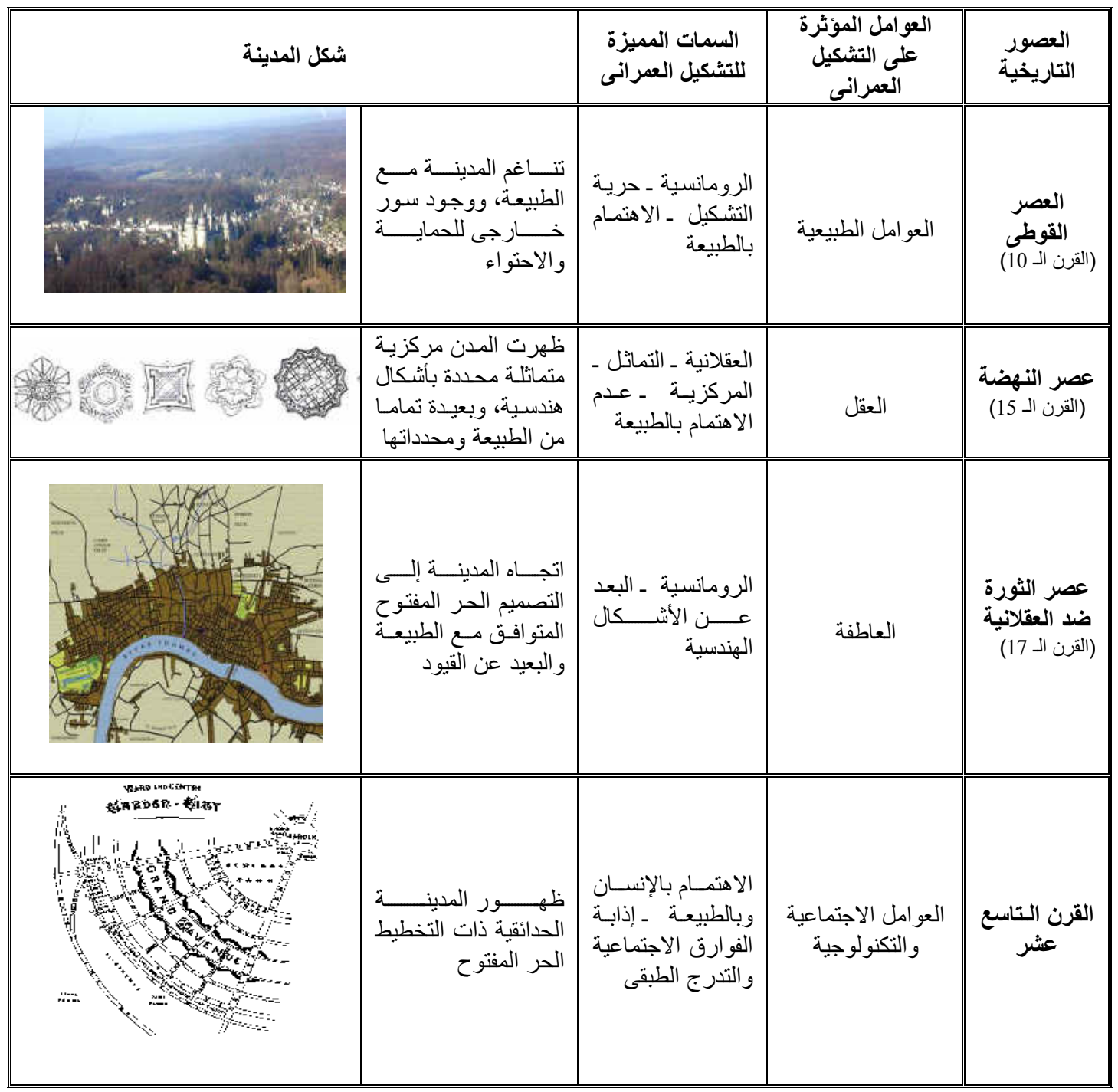

2 - 3 - العوامل المؤثرة على التثكيل العمرانى

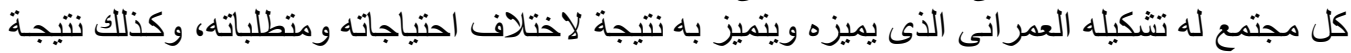

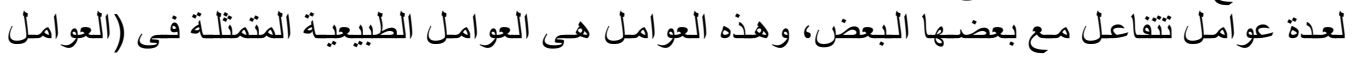

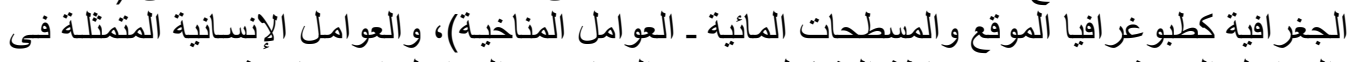

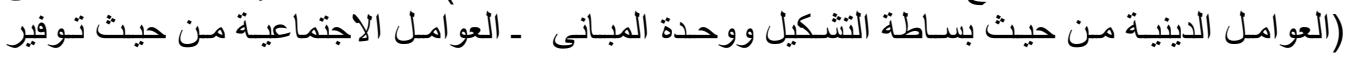

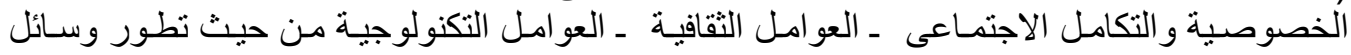
الحركة ـ العو امل الاقتصادية ـ العو امل السياسية ـ العو امل التشريعية). 
2 - 4 - ماهية عملية التثكيل العمرانى

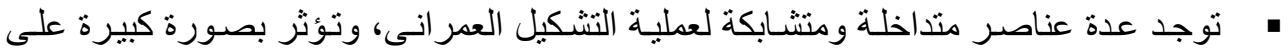
النتاج النهائى "البيئة العمر انية"، و هذه العناصر تختلف من وجهة نظر إلى أخرى كالآتى [2]:

جدول (2) عناصر علية التثكيل العمرانى

\begin{tabular}{|c|c|c|c|}
\hline $\begin{array}{l}\text { Salingaros } \\
\text { 22000 }\end{array}$ & $\begin{array}{l}\text { Kropf } \\
\text { 1996 }\end{array}$ & $\begin{array}{c}\text { Spereiregen } \\
\text { 1965 }\end{array}$ & 1960 Kevin Lynch \\
\hline 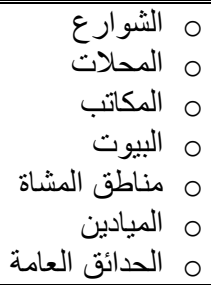 & ○ & 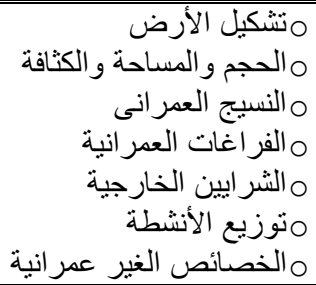 & 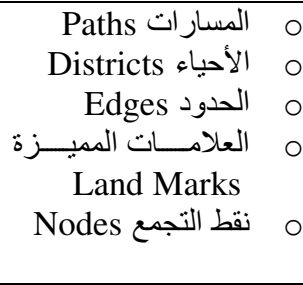 \\
\hline
\end{tabular}

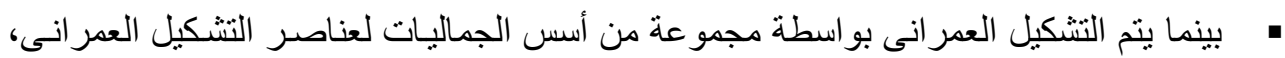

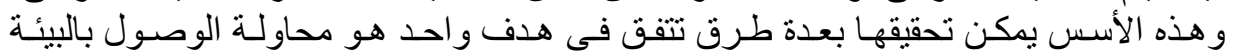

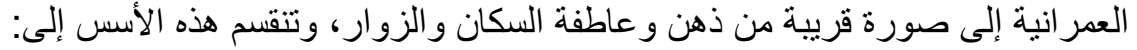

جدول (3) أسس جماليات عملية التثكيل العمرانى

\begin{tabular}{|c|c|c|}
\hline أسس جماليات الواجهات & أسس جماليات المسارات & أسس جماليات الفراغات \\
\hline 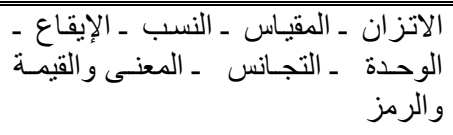 & 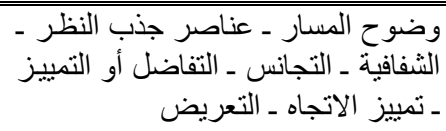 & الاحتواء ـ الاتزان ـ المقياس ـ النسب \\
\hline
\end{tabular}

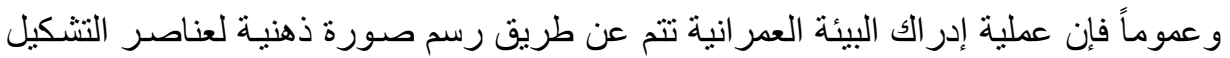

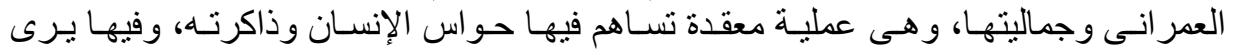

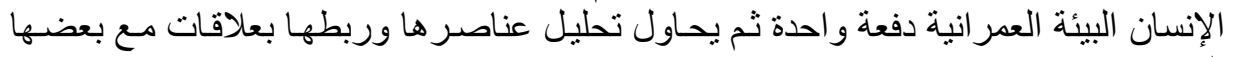

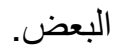

جدول (4) إدراك البيئة العمرانية

\begin{tabular}{|c|c|c|}
\hline العوامل المؤُثرة علية إدراك البيئة & مراحل إدراك البيئة العمرانية & خصائص أساسية لادراك البيئة \\
\hline التعريض ـ التشكيل ـ التكوين ـ المعنى & استقبال المؤثرات ـ ـ إضفاء معنى عليها & الانتباه ـ البساطة ـ التكوين \\
\hline
\end{tabular}

\section{3- ملامع التشكيل العمرانى لنطاقات المسطحات المائية}

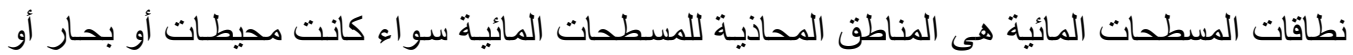

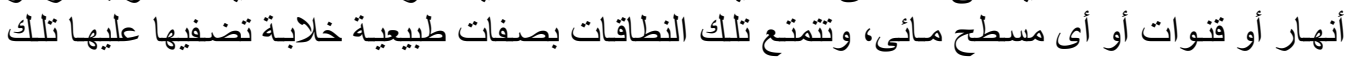


المسطحات المائية. وفى مصر تعرف نطاقات المسطحات المائية إداريـا على أنها المنطقة التى يتقابل

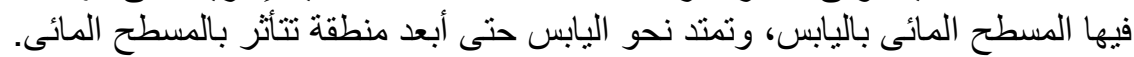

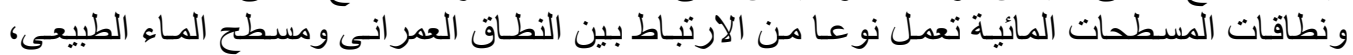

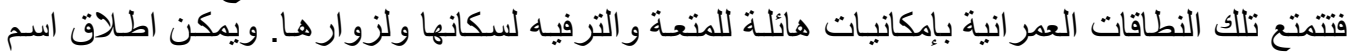

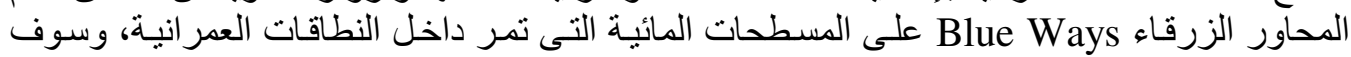

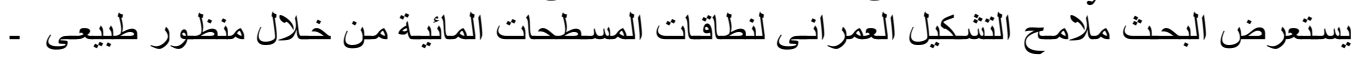

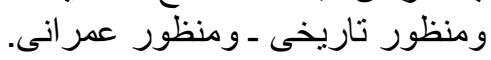

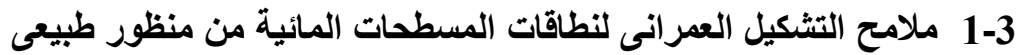

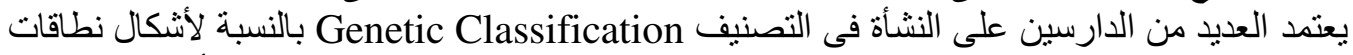

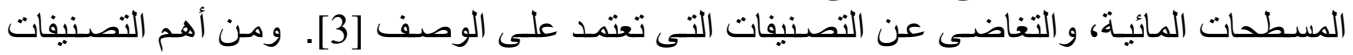
الرئيسية لنطاقات المسطحات المائية:

جدول (5) تصنيف نطاقات المسطحات المائية

\begin{tabular}{|c|c|c|c|}
\hline تصنيف فالنتين & تصنيف كوتن & تصنيف شييرد & تصنيف جونسون 1919م \\
\hline 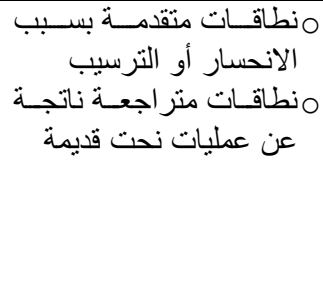 & منطاقات الأقاليميم غير الثابتة & 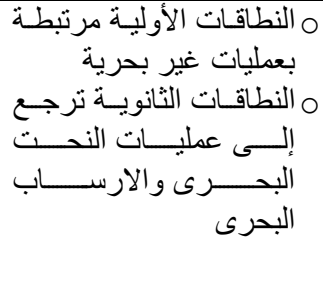 & 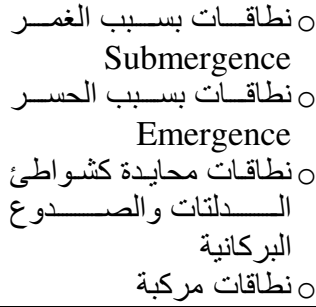 \\
\hline
\end{tabular}

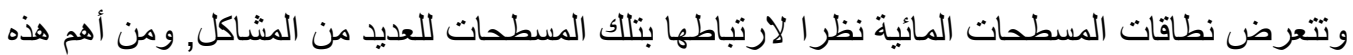

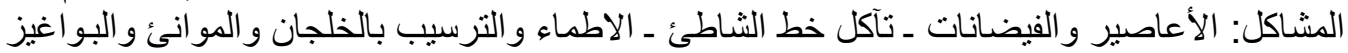

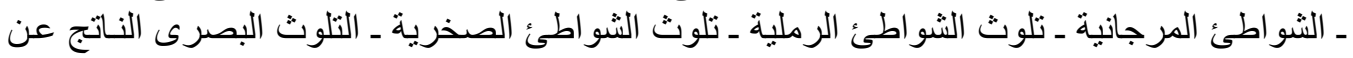

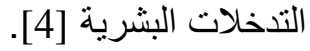

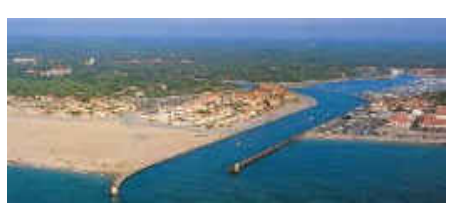

3-الاطماء بالخلجان و الموانى

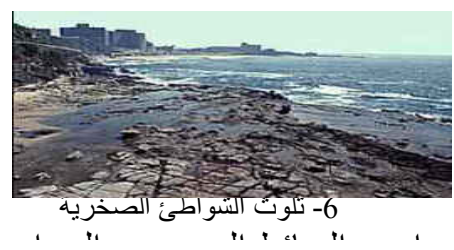

شكل (1) مثاكل نطاقات المسطحات المائية

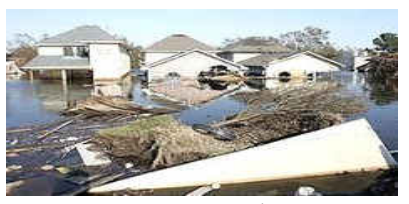

1- الأعاصبر و الفيضانات

2- 2 - تآكل خط الشاطئ
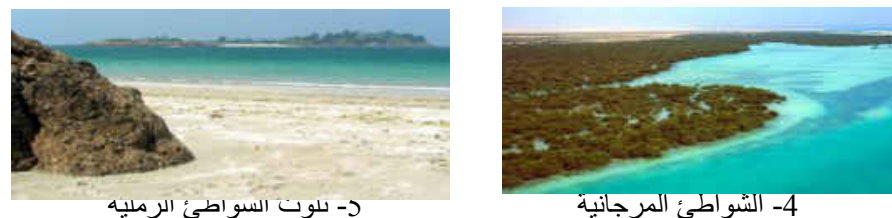

4- الشواطئ المرجانية

الوسائل التى تهدف إلى الحفاظ على خط الساحل، ويجب أن يكون التدخل البشرى الهادف إلى حماية

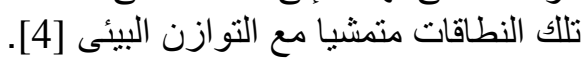




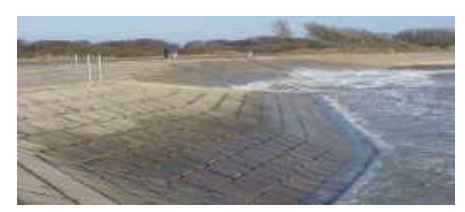

3- الجدار البحرى Revetments

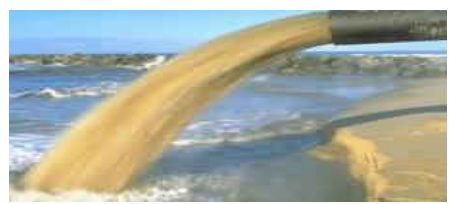

6each Fill التغذية بالرمال

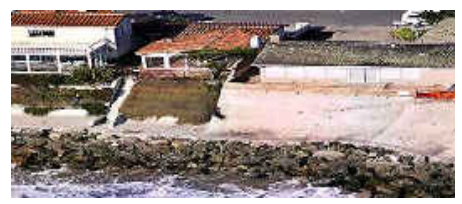

2- الحائط البحرى Seawall

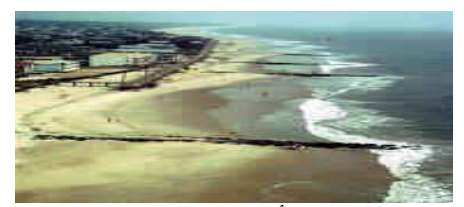

Groins - 5- الألسنة

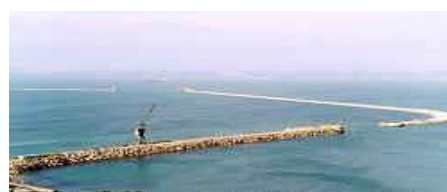

Breakwater الأمواج

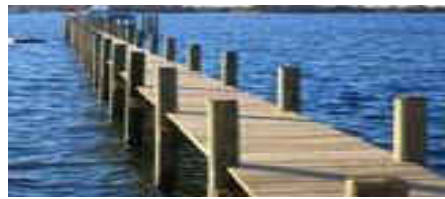

4- الرؤوس Bulkheads

شكل (2) طرق حماية نطاقات المسطحات المائية

2-3 ملامح التثكيل العمرانى لنطاقات المسطحات المائية من منظور تاريخى يشمل در اسة نطاقات المسطحات المائية عبر الحضـار ات المختلفة كالحضـار ات القديمة، و الاتجاهـات

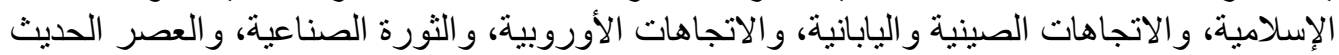

جدول (6) ملامح التثكيل العمر انى لنطاقات المسطحات المائية من منظور تاريخى

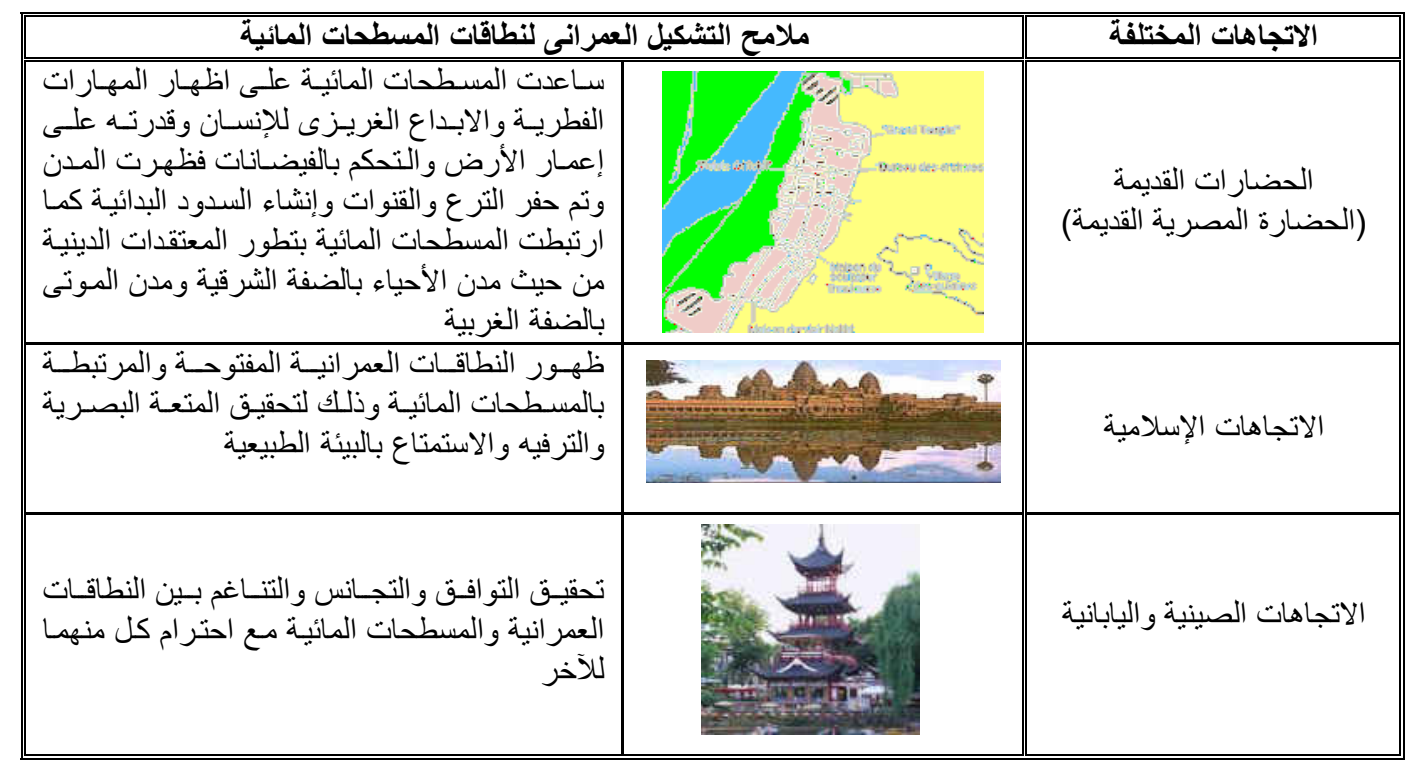


تابع جدول (6) ملامح التثكيل العمرانى لنطاقات المسطحات المائية من منظور تاريخى

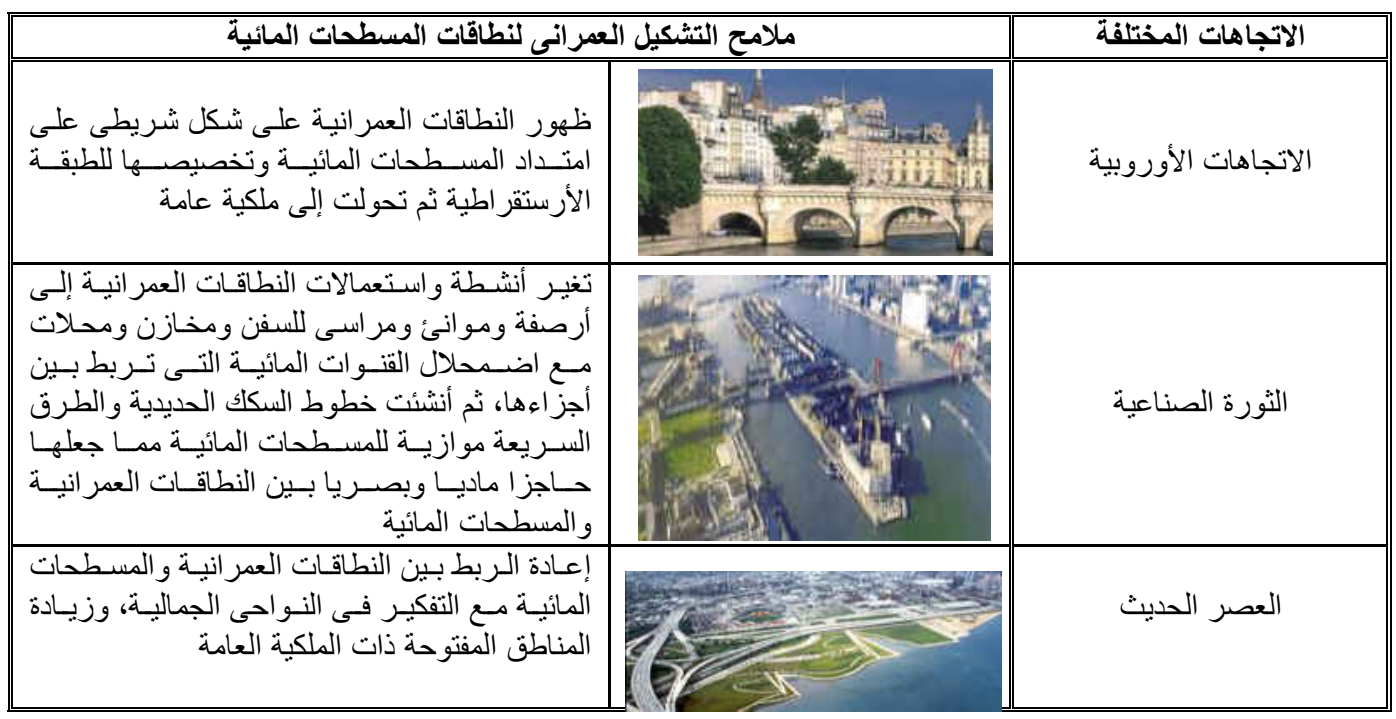

3-3 ملامح التثكيل العمرانى لنطاقات المسطحات المائية من منظور عمرانى

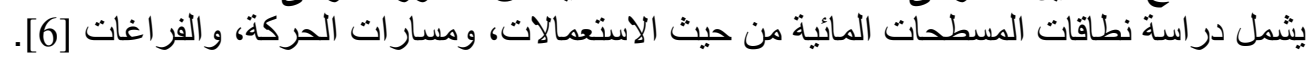
جدول (7) ملامح التثكيل العمرانى لنطاقات المسطحات المائية من منظور عمرانى

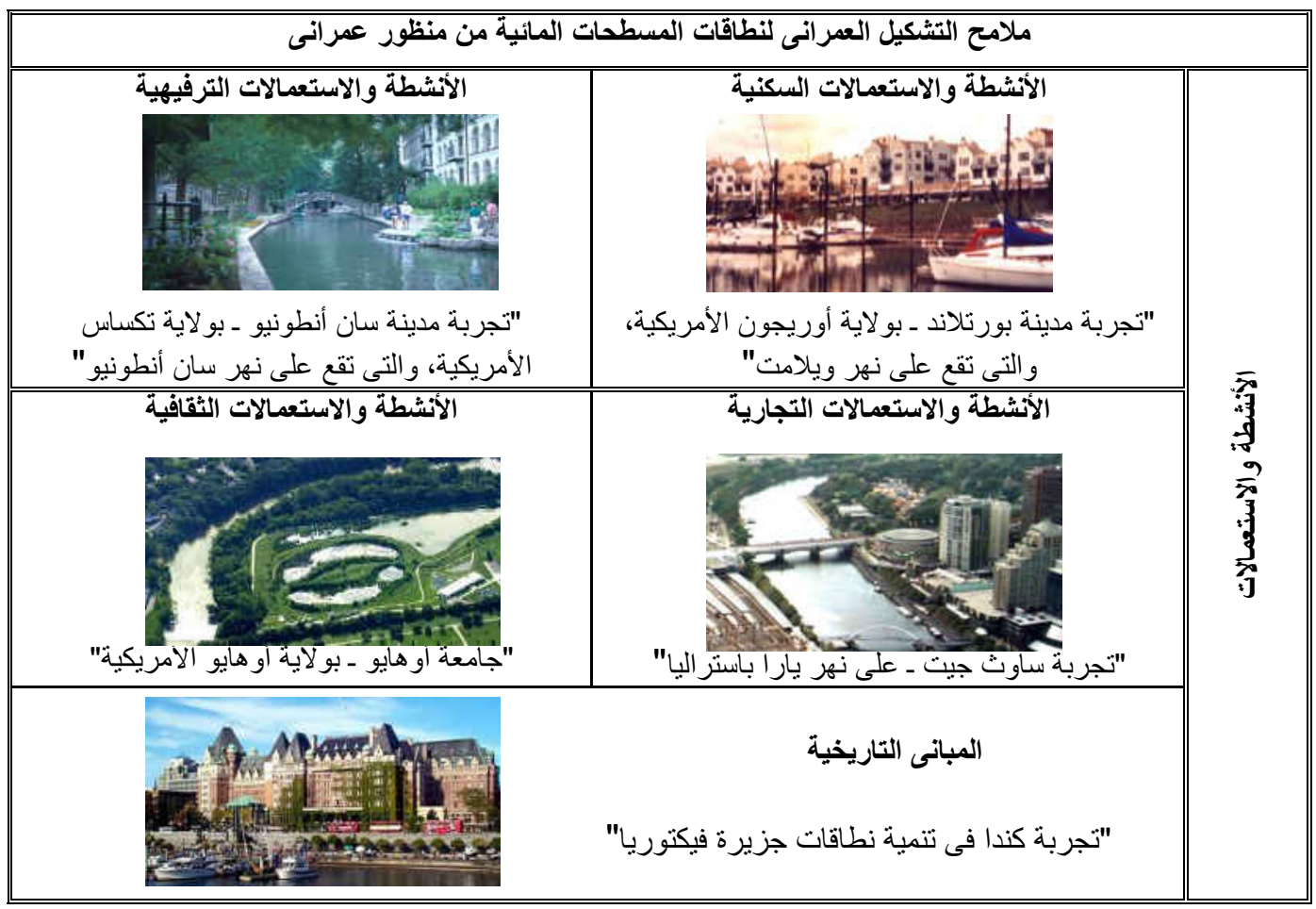


تابع جذول (7) ملامح التثكيل العمرانى لنطاقات المسطحات المائية من منظور عمرانى

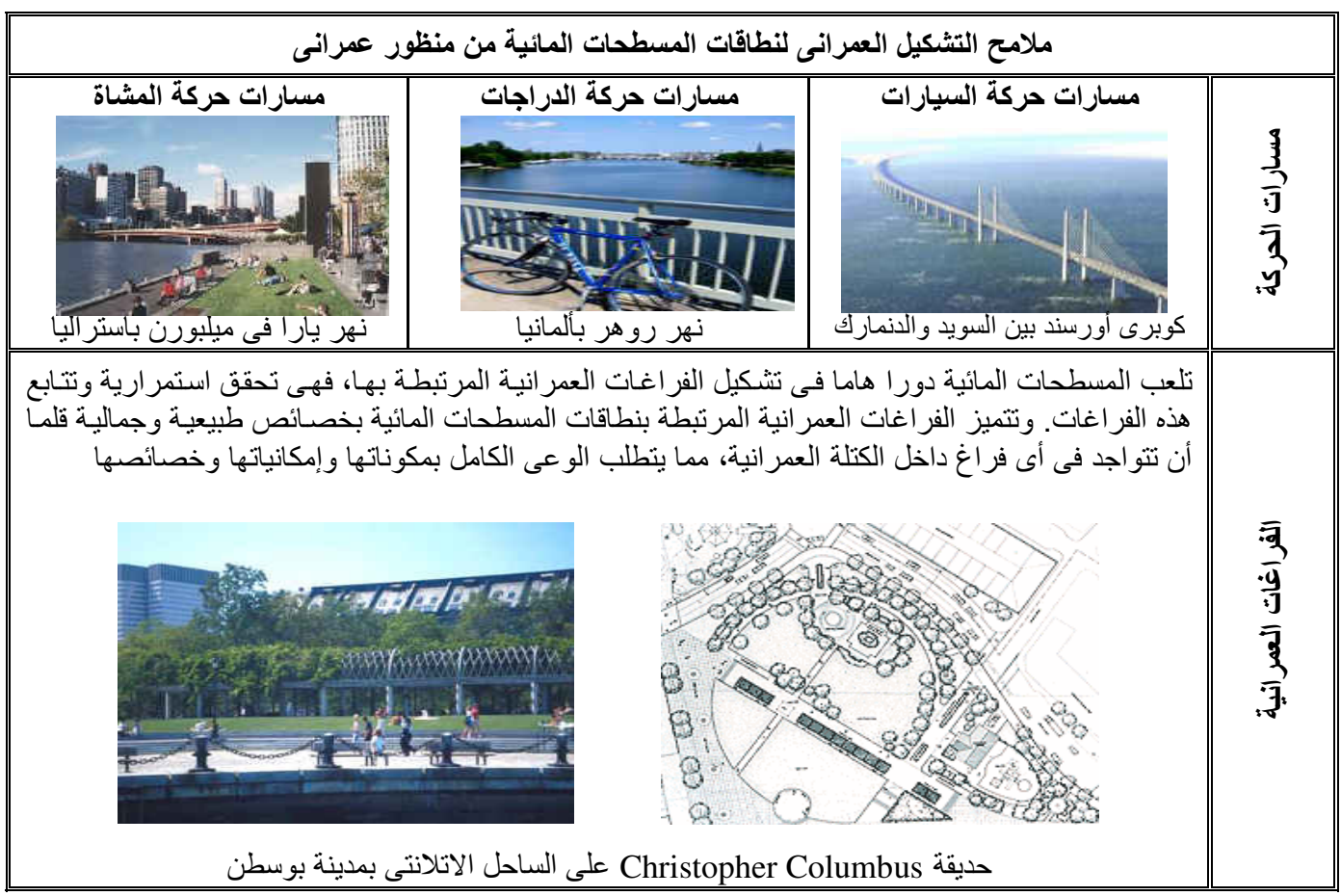

\section{4- الاراسة الميدانية

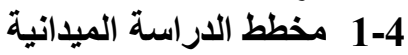

أهمية الدراسة الميدانية:

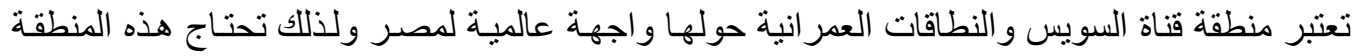

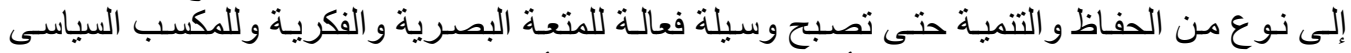

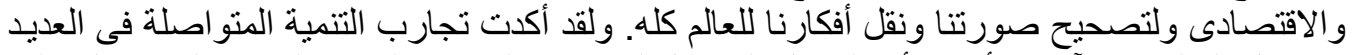

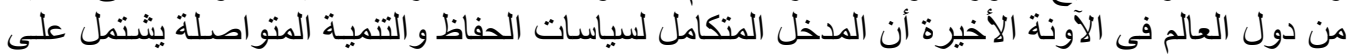

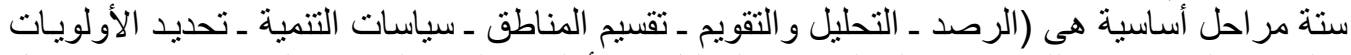

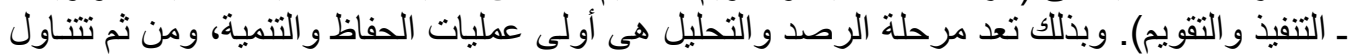

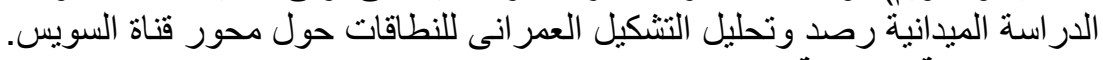

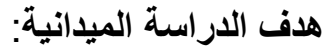
تهدف الدراسة إلى رصد وليدانة: تصليل ملامح التشكيل العمر انى للنطاقات العمر انية حول محور قناة السويس. تحديد نطاقات الاراسة الميدانية:

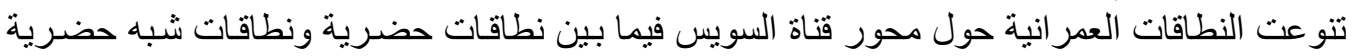

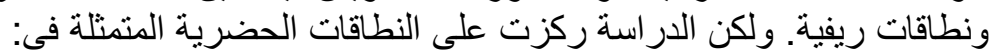

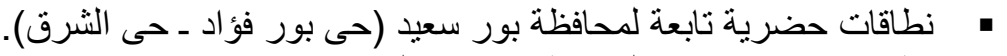

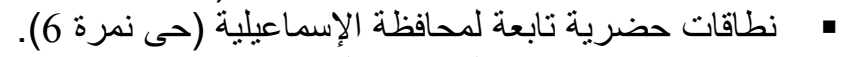

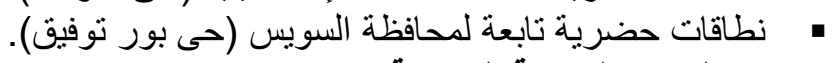
طرق جمع معلومات الدراسة الميدانية تلنية:

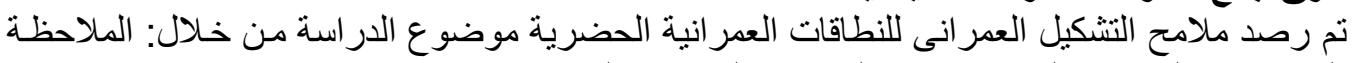
الثخصية ـ التصوير الفوتوغرافى ـ المصادر المكتيبة ـ المقابلات. 
منهج تحليل النطاقات العمرانية:

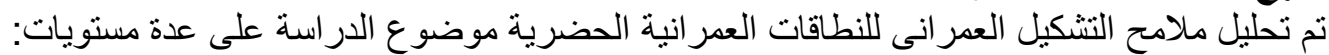

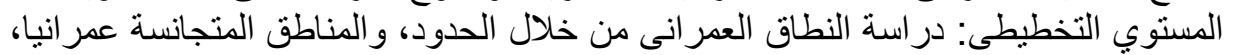

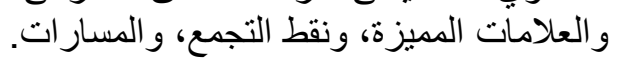

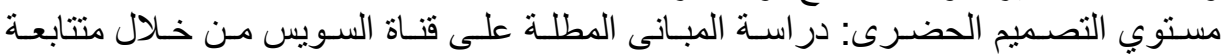

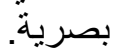

المستوي المعمـارى: دراسـة نموذج المبنـى المميز فـى النطـاق العمر انسى من خـلال عناصر تشكيل واجهات المبنى، و أسس تشكيل واجهات المنئ المبنى.

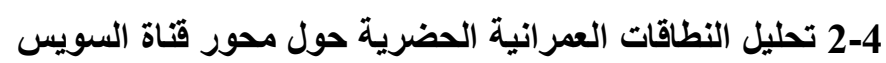
1-2-4 النطاقات العمرانية الحضرية حول محور قناة السويس والتابعة لمحافظة بور سعيد

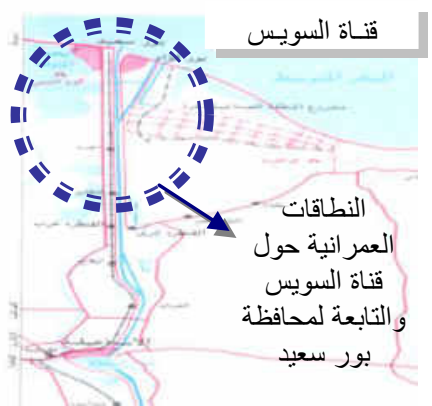

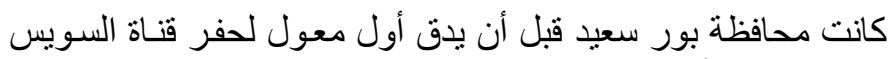

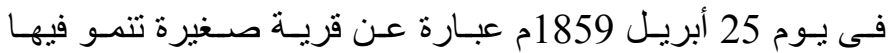

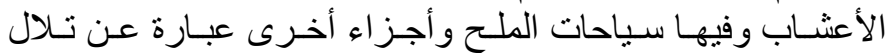

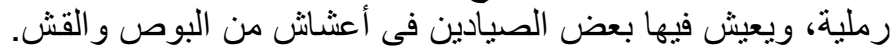

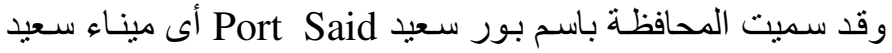

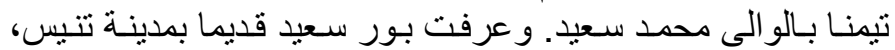

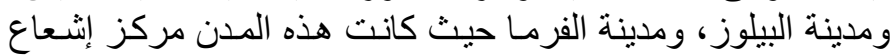

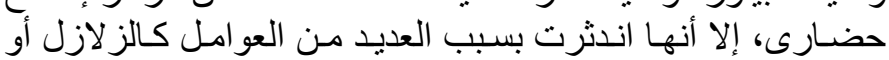

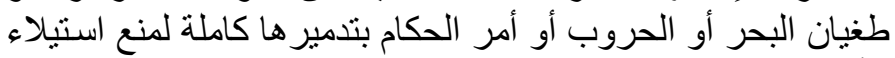

شكل (3) النطاقات العمر انبة حول قناة

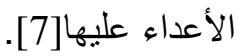

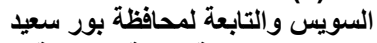

المصدر: الهيئة العامة للمساحة بردي

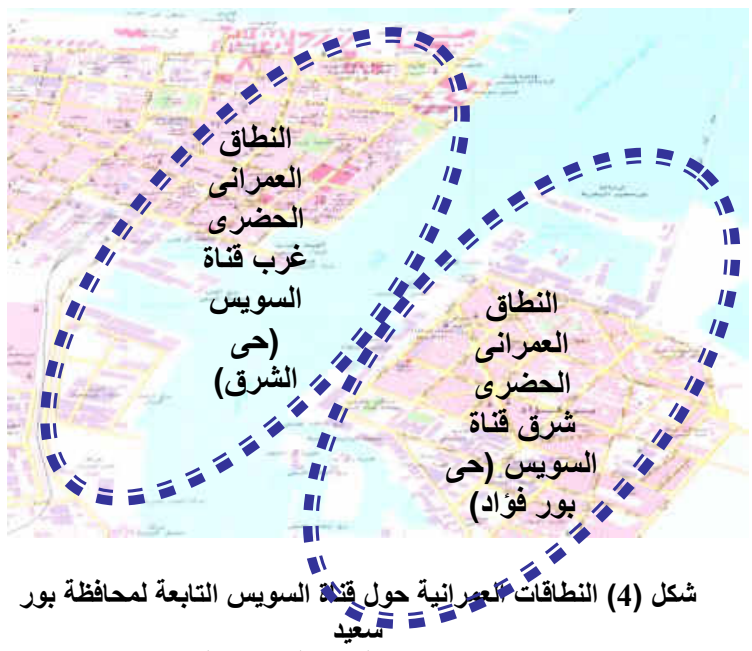

المصدر: الهيئة الكعامة للمساحة
تتنوع النطاقات العمر انيـة حول محور قنـاة

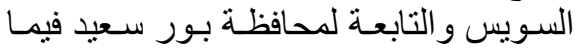

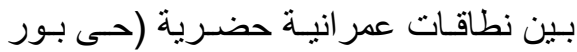
فؤاد ـ حى الثرق)، ونطاقات عمر انيـة شبه بـه

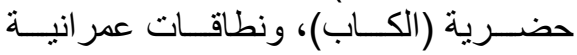
عثـوائية (عزبـة الجنـاين)، ونطاقـات ريفيـة (لطية (الطينة). وتركز الدراسـة علـى النطاقـات العمر انيـة

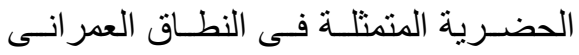

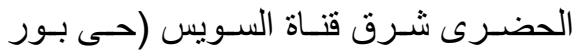

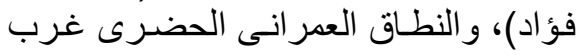
قناة السويس (حى الشرق) 
ويمكن رصد أهم ملامح التشكيل العمر انى لحى بور فؤاد كما يظهر بالجدول الآتى:

جدول (8) التثكيل العمر انى لحى بور فؤاد بمحافظة بور سعيد

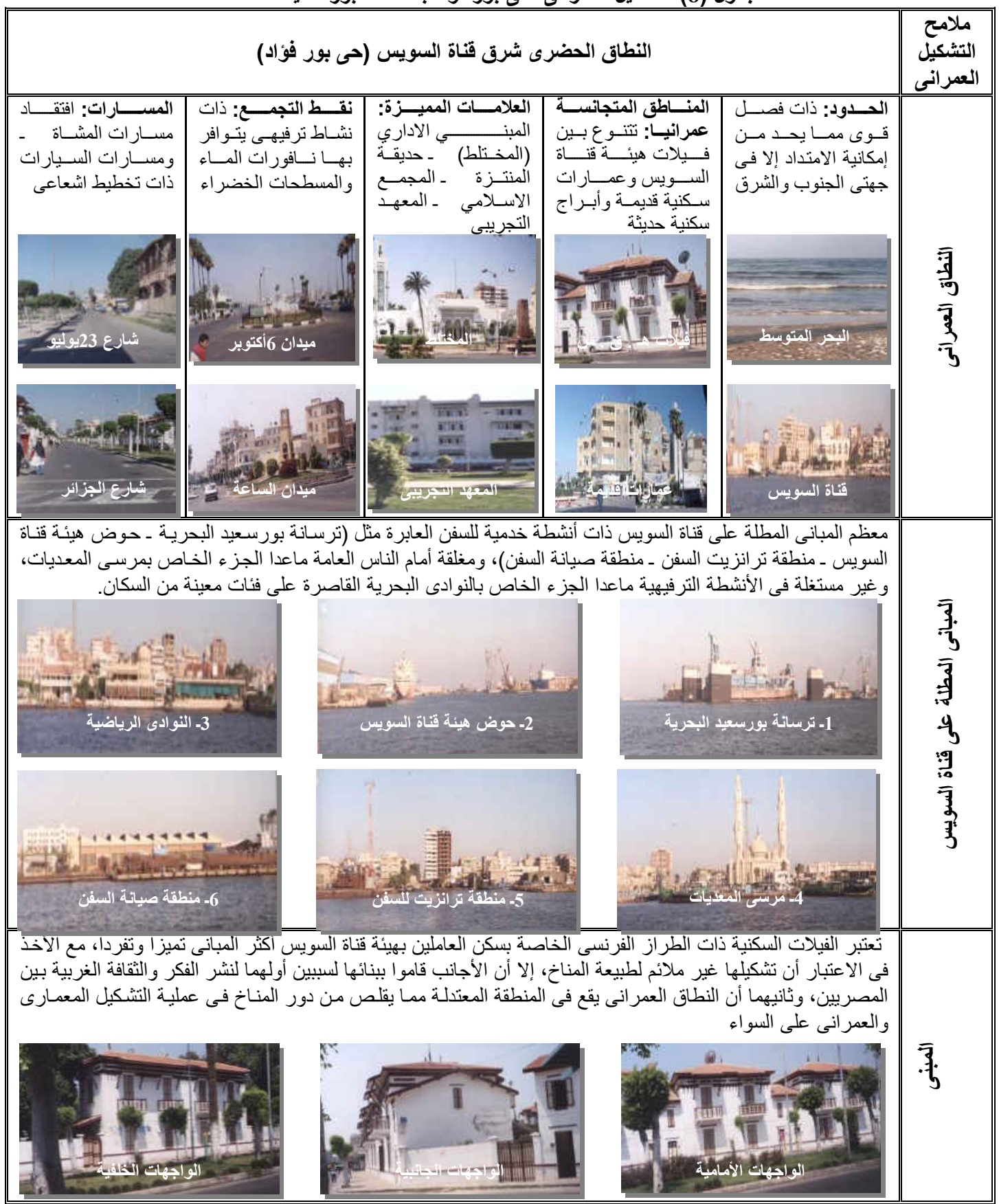


ويمكن رصد أهم ملامح التشكيل العمر انى لحى الثرق كما يظهر بالجدول الآتى: جدول (9) التثكيل العمرانى لحى الثرق بمحافظة بور سعيد

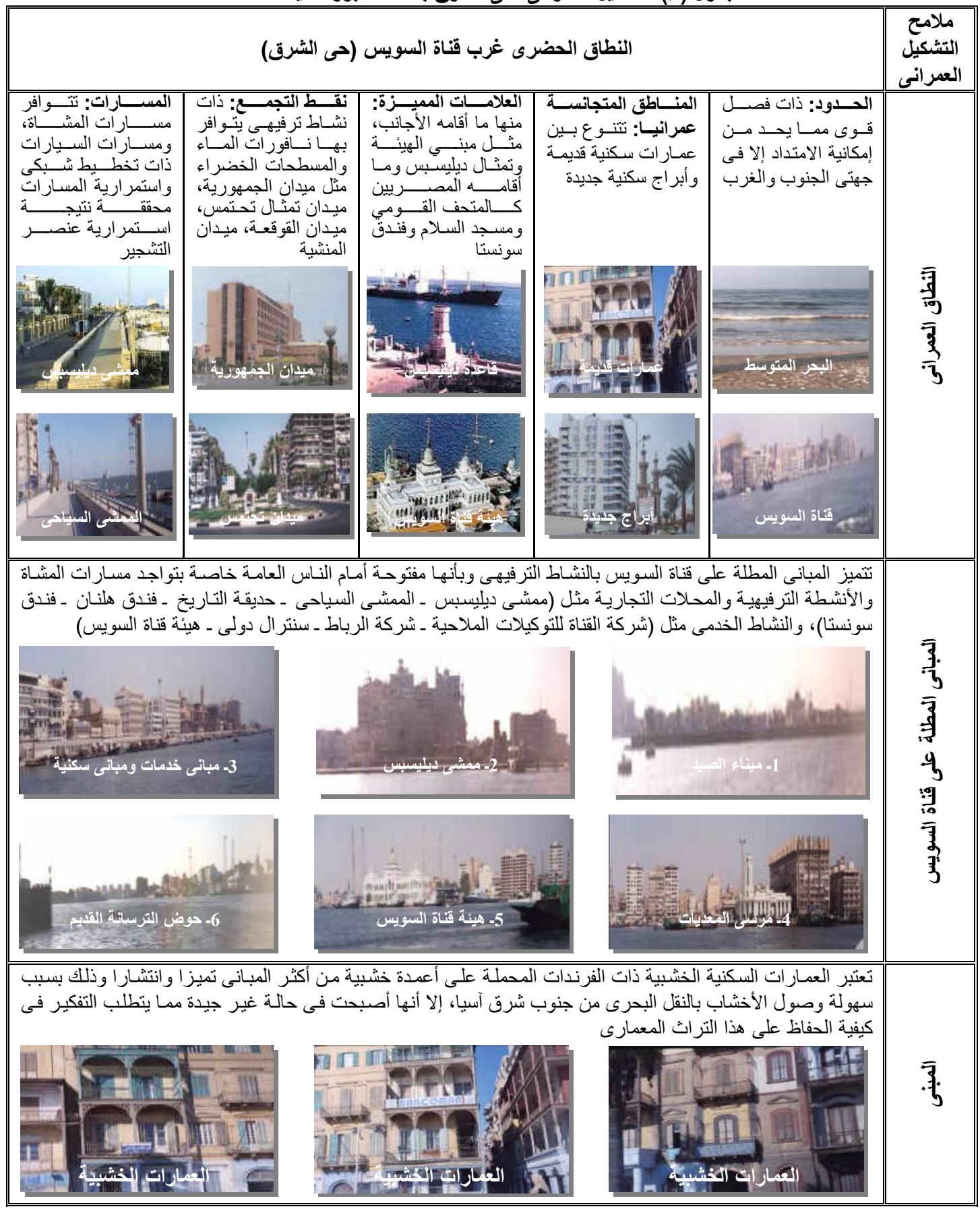


2-2-4 النطاقات العمرانية الحضرية حول محور قناة السويس والتابعة لمحافظة الإسماعيلية

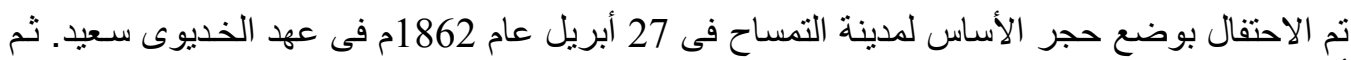

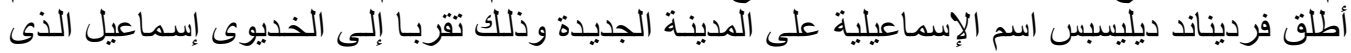

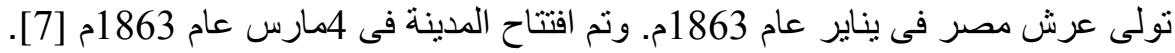

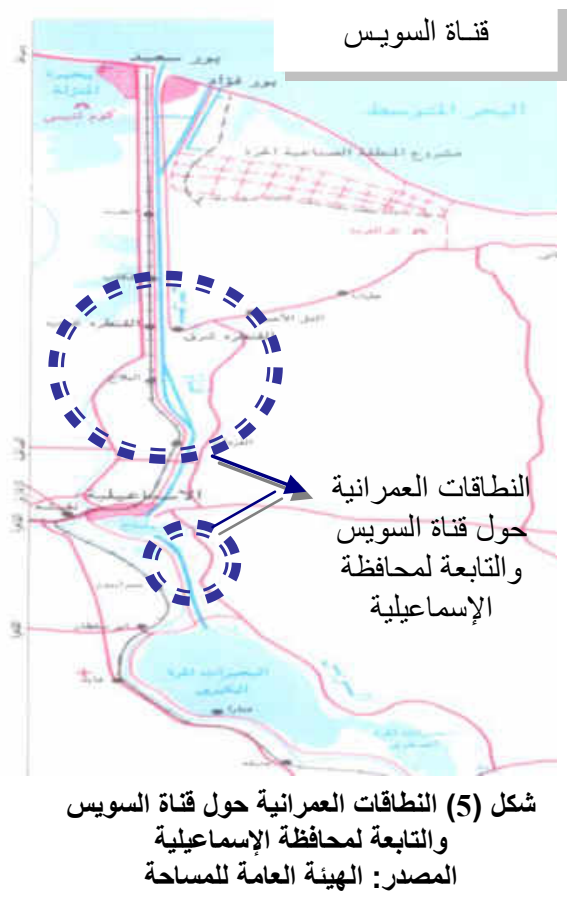

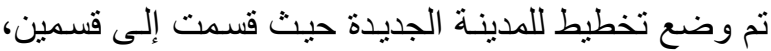

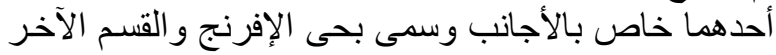

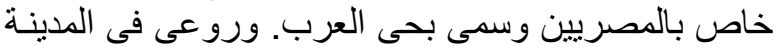

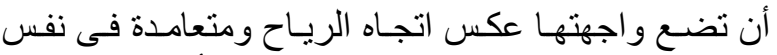
الوقت مع مسار الشمس مما جعلها مشتى للأجانب.

تتتوع النطاقات العمر انية حول محور قناة السويس و التابعـة

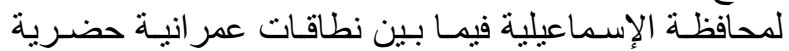

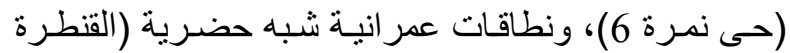
شرق ـ القنطرة غرب)، ونطاقات ريفية (البلاح ـ الفردان).

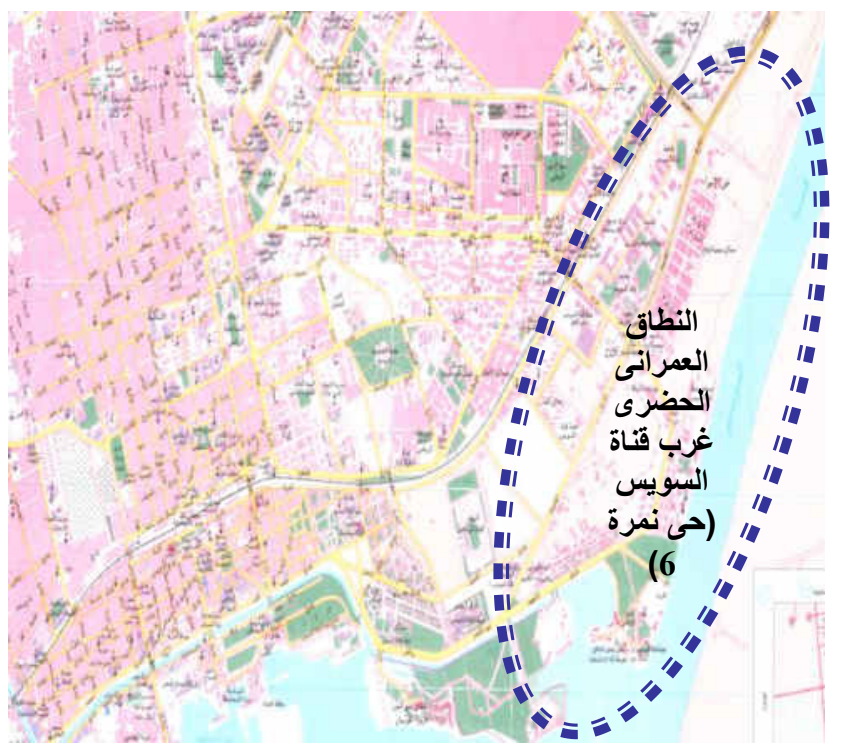

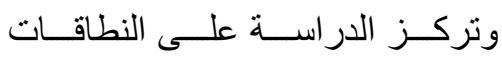

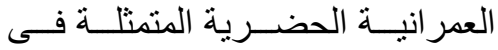
النطاق العمر انى الحضرى غربة العرب قناة السويس (حى نمرة 6) النطرئ

شكل (6) النطاقات العمرانية الحضرية حول قناة السويس والتابعة لمحافظة الإسماعيلية المبلية المصدر: الهيئة العامة للمساحة الاسماعية 
ويمكن رصد أهم ملامح التنكيل العمر انى لحى نمرة 6 كما يظهر بالجدول الآتى:

جدول (10) التثكيل العمر انى لحى نمرة 6 بمحافظة الإسماعيلية

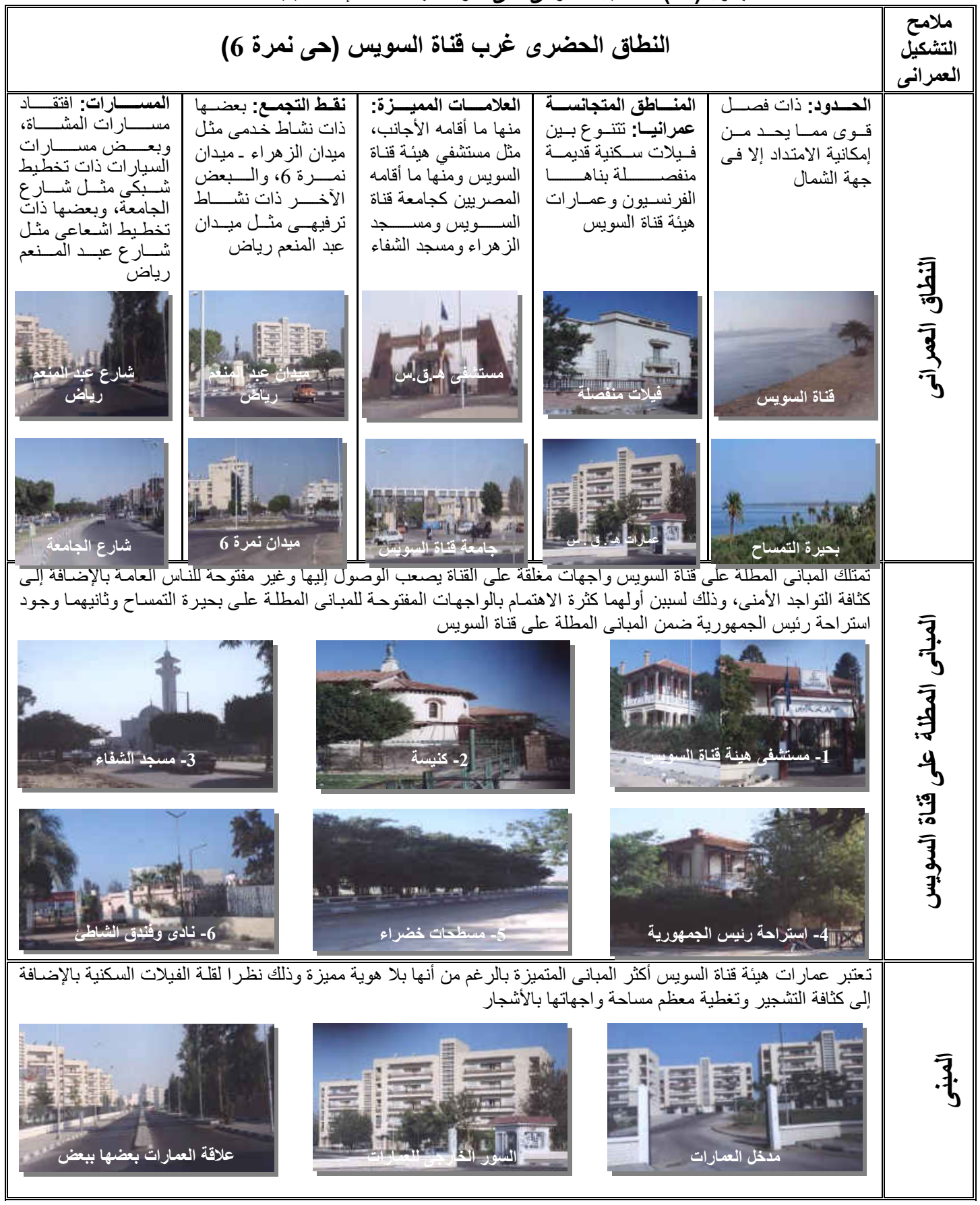


3-2-4 النطاقات العمرانية الحضرية حول محور قناة السويس والتابعة لمحافظة السويس

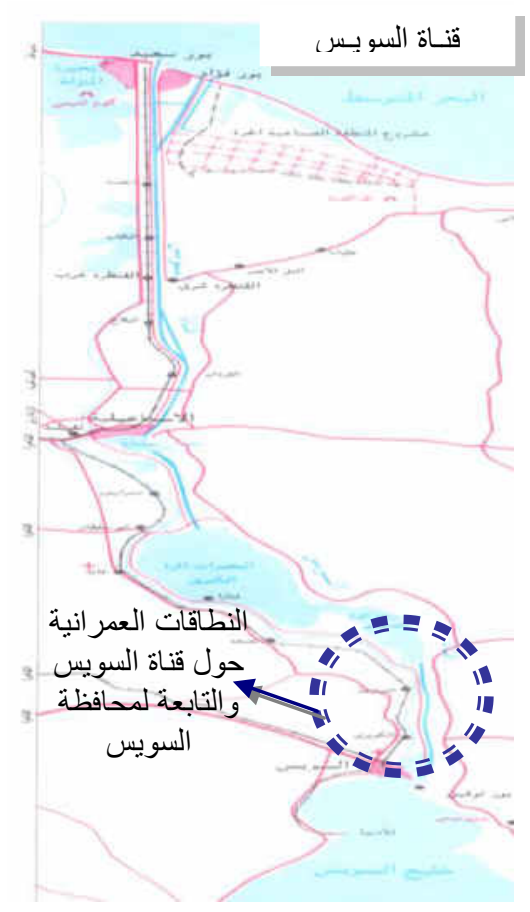

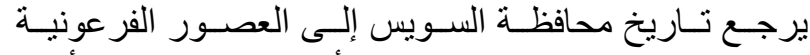

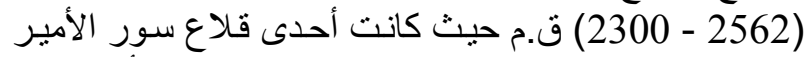

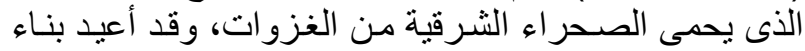

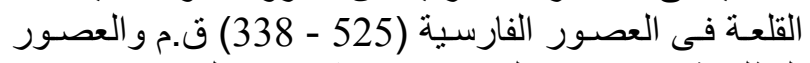

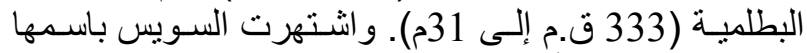

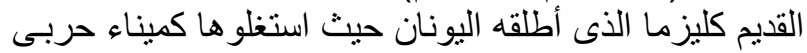

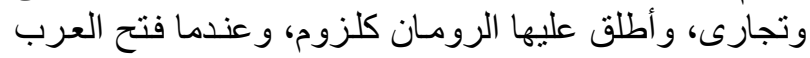

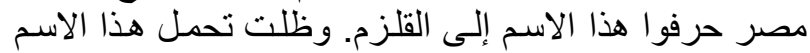

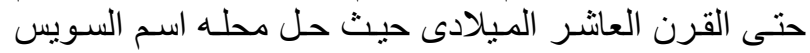

تلتنوع النطاقات العمر انيـة حول محور قنـاة السويس والتابعـة

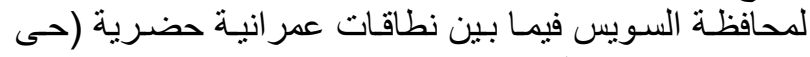

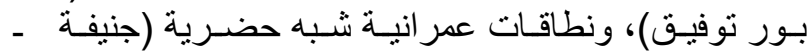
الثلوفة)، ونطاقات زر اعية ونطى الجناين).

شـكل (7) النطاقـات العمرانيـة حـول قنـاة السـويس والتابعـة لمحافظـة

المصدر: الهيئة العامة للمساحة

$$
\text { السويس }
$$

وتركز الدر اسـة على النطاقـات العمر انيـة الحضـرية المتمثلة فى النطـاق العمر انى غرب قنـاة السويس (حى بور توفيق).

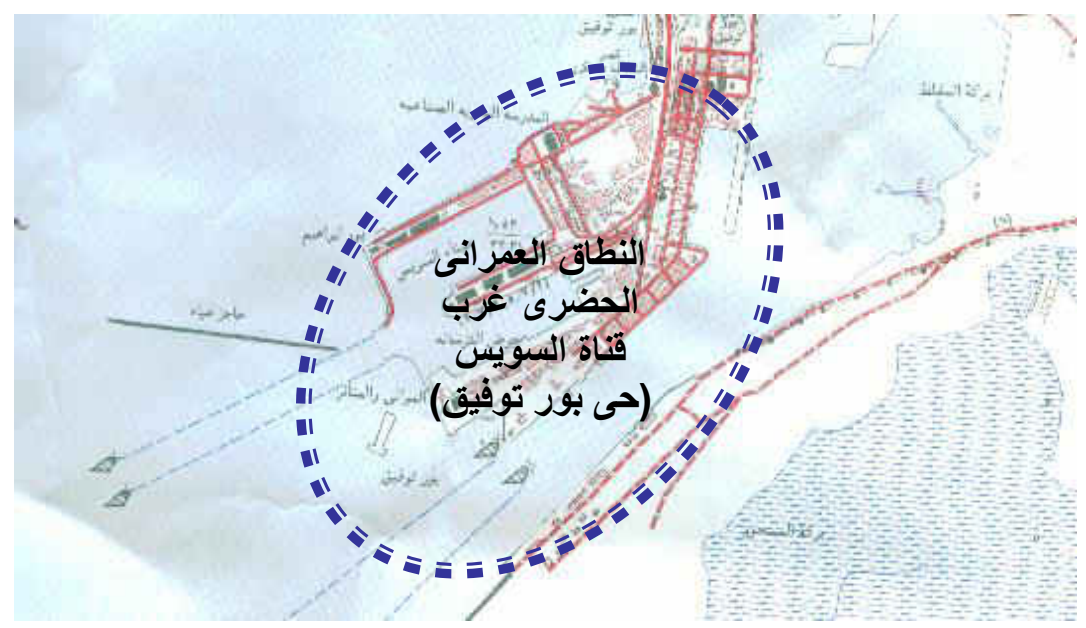

شكل (8) النطاقات العمرانية الحضرية حول قناة السويس والتابعة لمحافظة السويس المدات

المصدر: الهيئة العامة للمساحة المويسة 
ويمكن رصد أهم ملامح التشكيل العمر انى لحى بور توفيق كما يظهر بالجدول الآتى: جدول (11) التشكيل العمرانى لحى بور توفيق بمحافظة السويس بولئ لفي

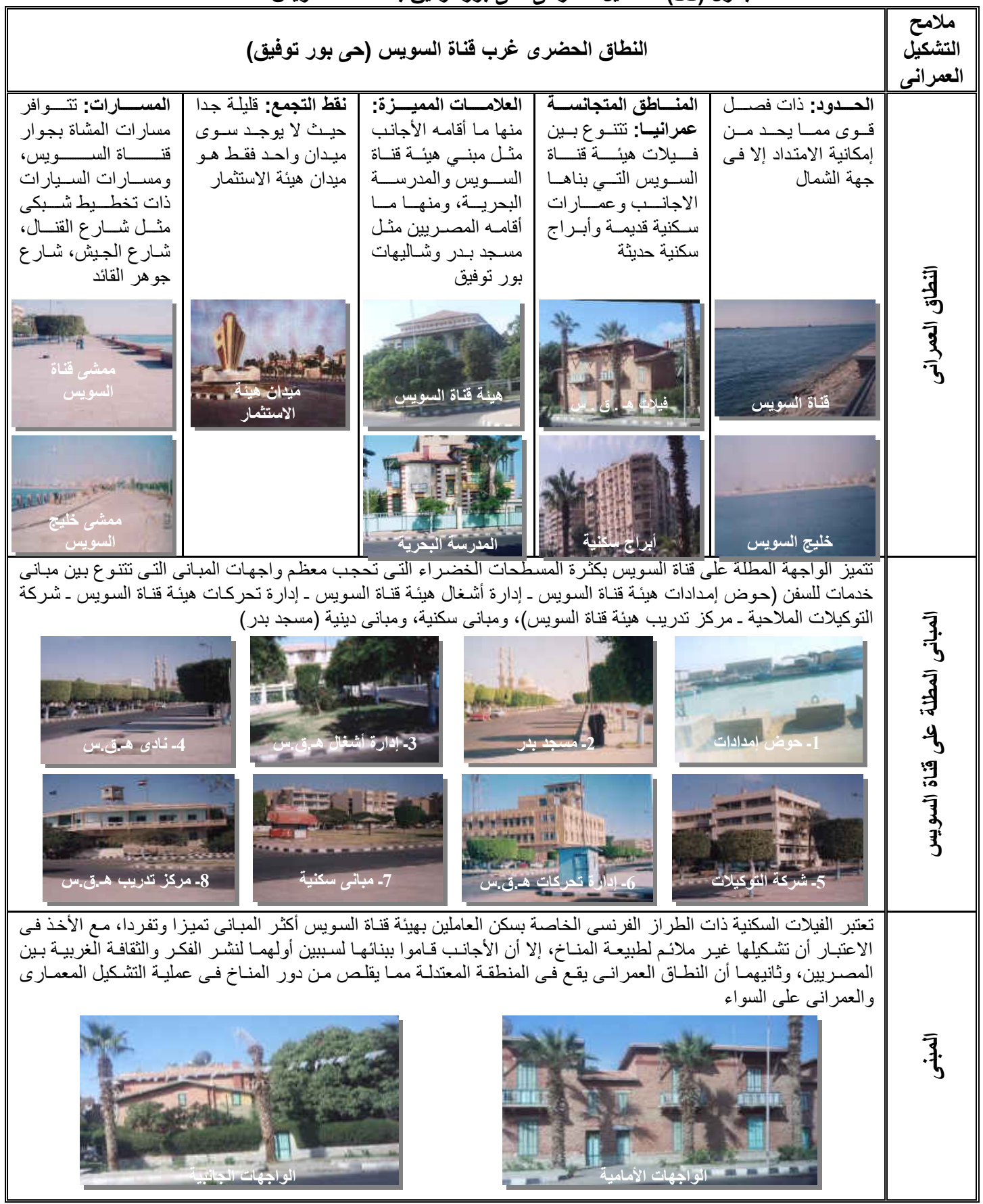




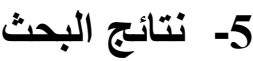

تحتل قضية التشكيل العمر انى حيز ا كبير ا من اهتمام المصممين العمر انيين، حيث بعتبر اتخاذ

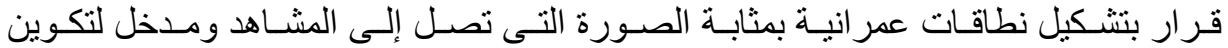

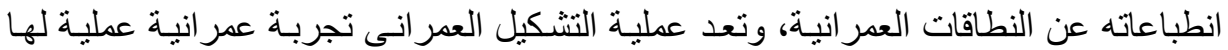

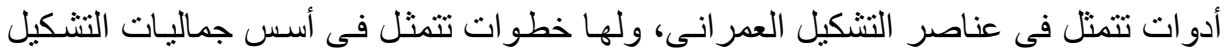

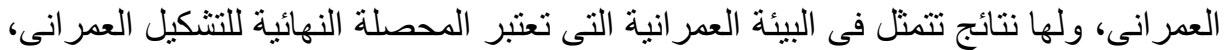

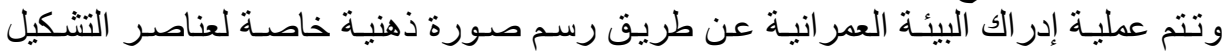

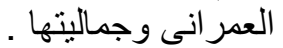

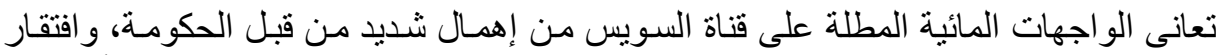

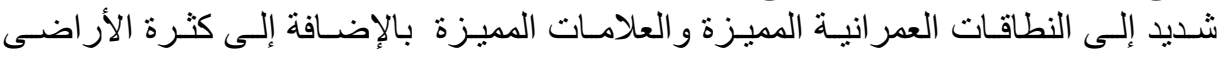

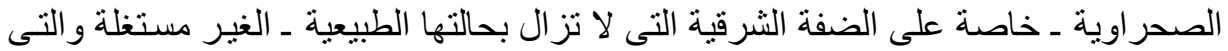

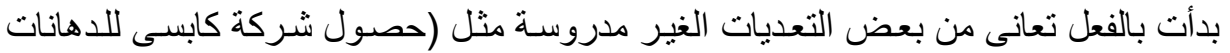

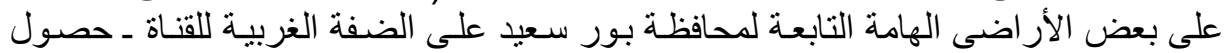

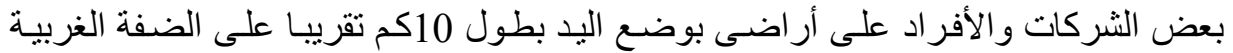

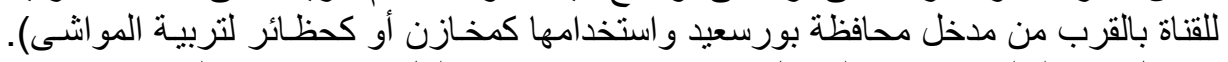

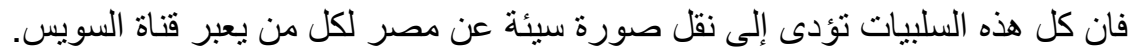

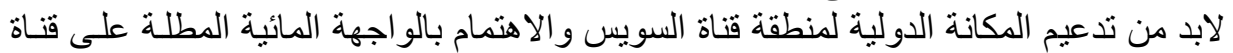

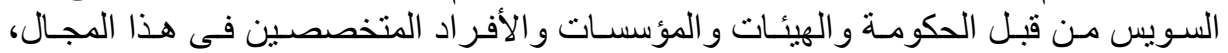

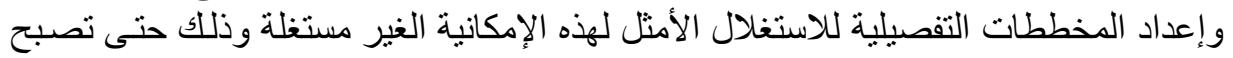

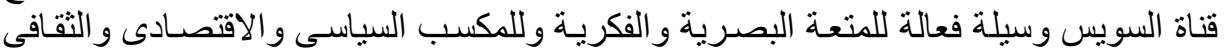
ولتصحيح صورنتا ونقل أفكارنا للعالم كله.

جلول (12) نتائج الدراسة الميدانية علي النطاقات العمرانية الحضرية علي محور قناة السويس

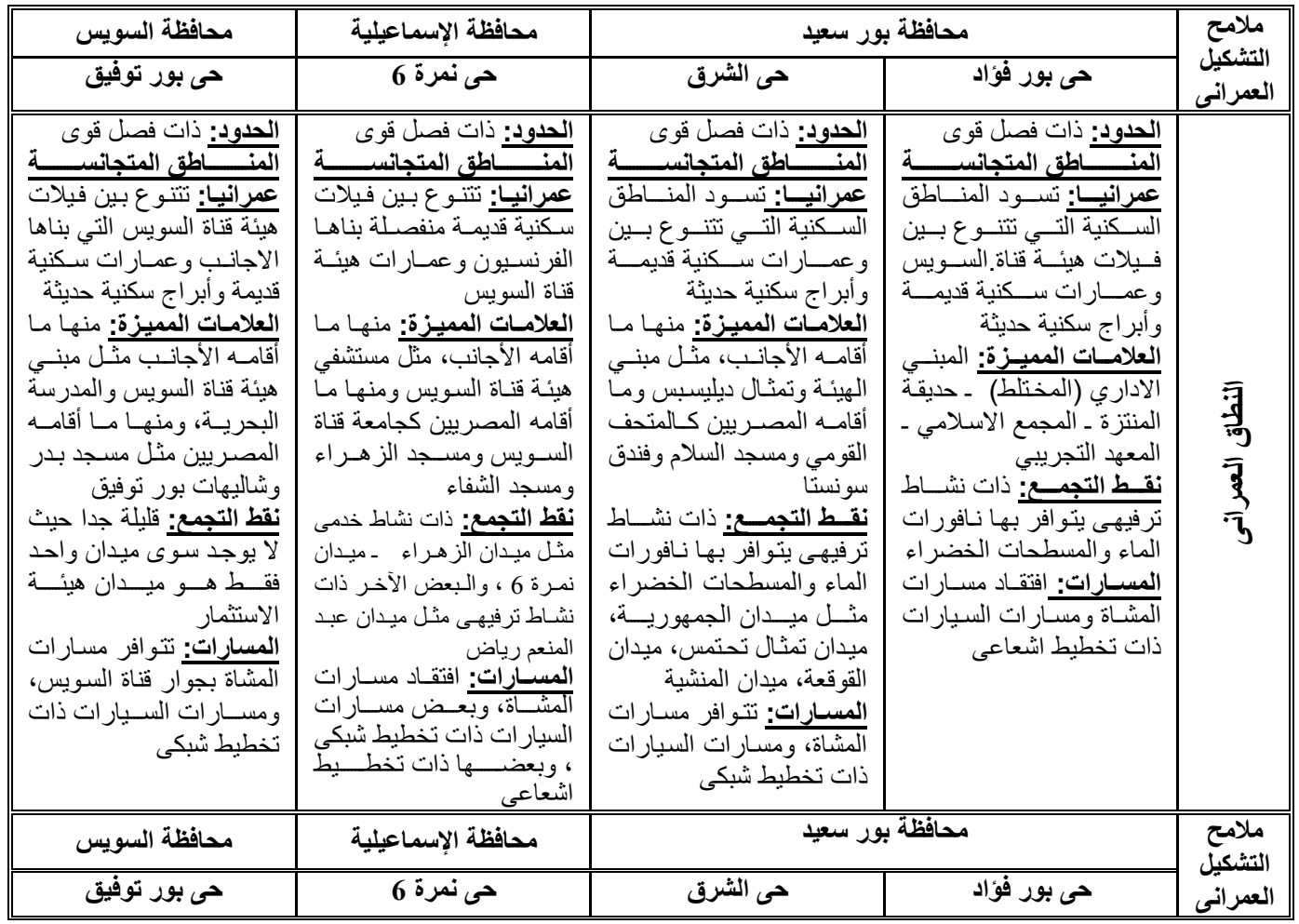




\begin{tabular}{|c|c|c|c|c|}
\hline 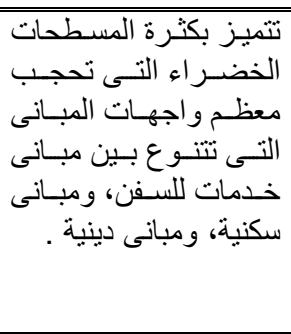 & 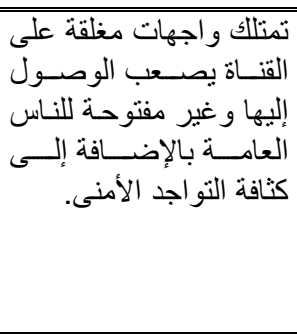 & 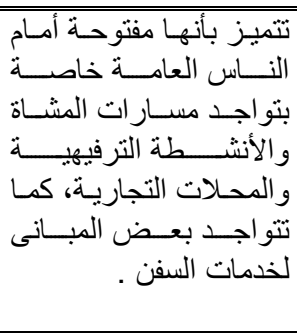 & 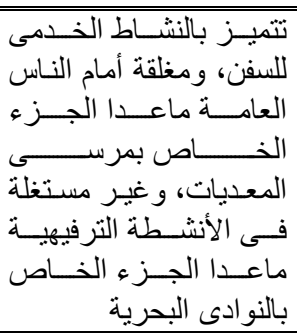 & 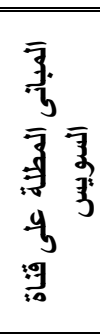 \\
\hline 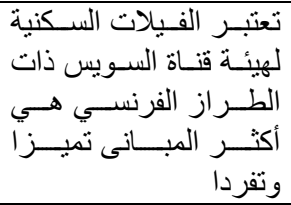 & 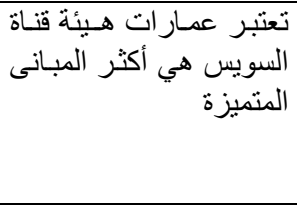 & 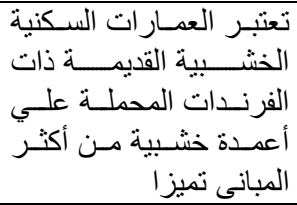 & 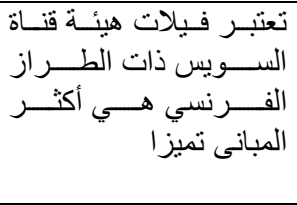 & 車 \\
\hline
\end{tabular}

\section{6- - توصيات البحث}

من خلال الدراسة النظرية والميدانية يمكن الخروج بمجمو عة من التوصيات على التى عدة مستويات:

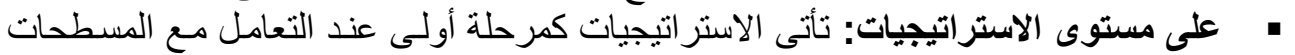

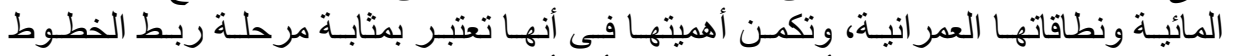

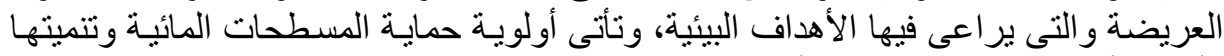

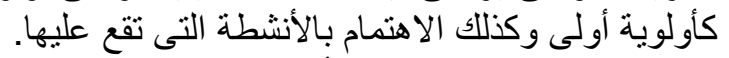

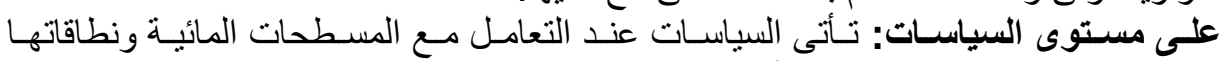

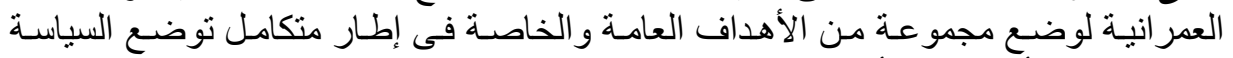

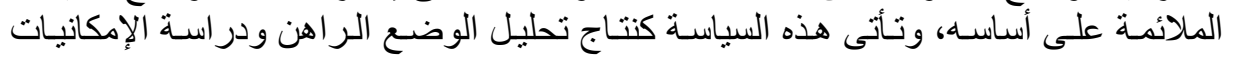

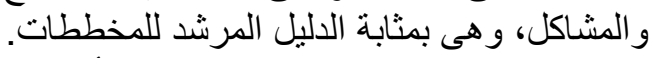

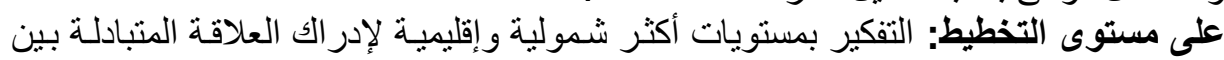

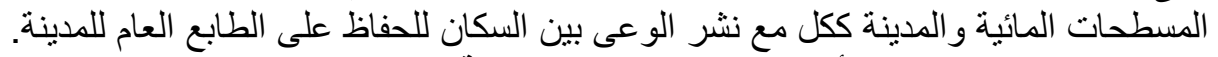

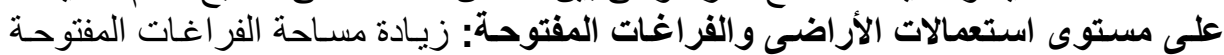

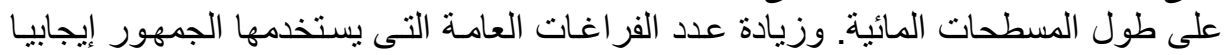
لممارسة العديد من الأنشطة.

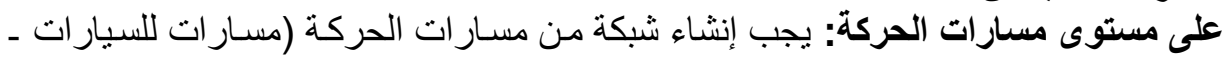

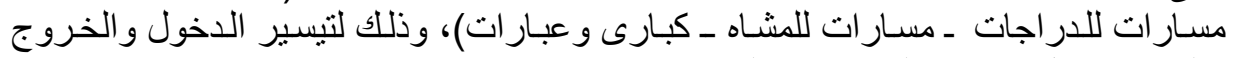
والحركة داخل نطاقات المسطحات المات مائية.

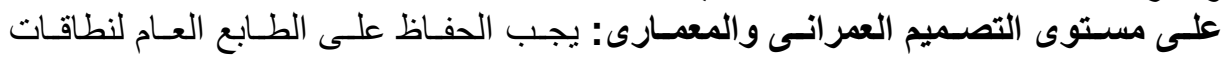

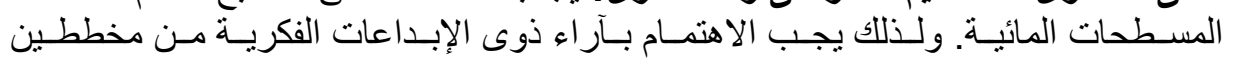

علمى مسيتوى التصميم البيئح وتنسيق الموقع: بجب التحكم في الاستثمار ات الاقتصسادية،

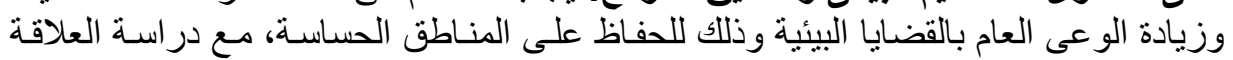

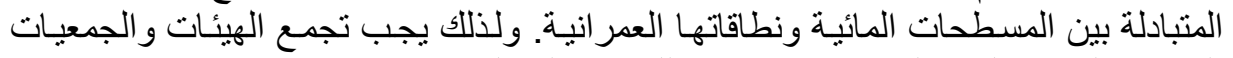

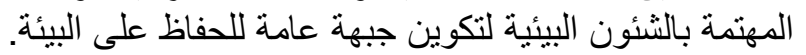

1. التونى، سيد. (1983). "الطـابع المعدـارى و العمر انى لمنـاطق التعمير الجديدة فى مصـر". 
2. Guy. (2003)." The Morphology of Spatial Character", planning institute of Australia. Queens land.

3. محسوب, محمد. (2002). "جغر افية البحار و المحيطات". القاهرة.

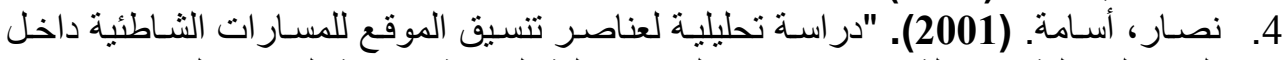

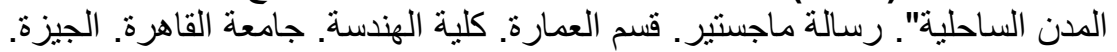

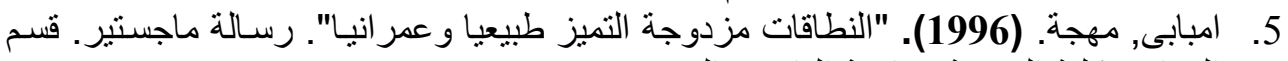

العمارة. كلية الهندسة. جامعة القاهرة. الجيزة.

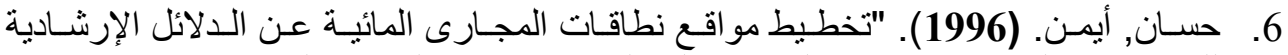

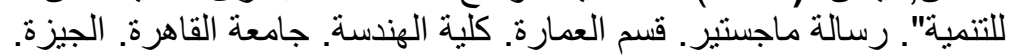

7. البنهاوى، محمد. (2000). "قناة السويس وتاريخ مر من هنا". القاهرة. 